\title{
Pengembangan Usaha Ekonomi Produktif pada Dasawisma 2 RT 01 RW 11 Desa Makamhaji Kecamatan Kartosuro Kabupaten Sukoharjo
}

\author{
Setyowati* dan Wiwit Rahayu \\ Program Studi Agribisnis, Universitas Sebelas Maret, Surakarta, Jawa Tengah \\ *Corresponding author: setyowati@staff.uns.ac.id
}

\begin{abstract}
ABSTRAK
Dasawisma memiliki potensi untuk meningkatkan kesejahteraan keluarga melalui usaha produktif dari ibu-ibu anggota dasawisma. Sebagian anggota dasawisma 2 Dusun Gobayan RT 01 RW XI Desa Makamhaji memiliki keterampilan dalam pembuatan olahan pangan tetapi belum dikembangkan. Masalah yang dihadapi adalah kurangnya pemahaman tentang kewirausahaan dan keterbatasan peralatan produksi. Pengabdian ini dilakukan untuk mengatasi masalah tersebut. Kegiatan yang dilakukan meliputi pelatihan kewirausahaan, introduksi alat produksi berupa alat pembuat stik, timbangan dan sealer, serta pendampingan. Hasil dari kegiatan pengabdian ini adalah ibu-ibu anggota dasawisma memiliki pengetahuan tentang kewirausahaan, termotivasi untuk berwirausaha, dan memiliki alat produksi yang dapat digunakan untuk melakukan usaha pembuatan stik. Hasil monitoring dan evaluasi menunjukkan bahwa ibu-ibu anggota dasawisma telah melakukan pembuatan stik aneka rasa kemudian dijual dengan cara dititipkan ke warung-warung, dijual online, dan juga menerima pesanan. Kegiatan pengabdian ini telah memunculkan usaha ekonomi produktif yang bermanfaat untuk menambah pendapatan rumah tangga ibu-ibu anggota dasawisma.
\end{abstract}

Kata Kunci: dasawisma, kewirausahaan, usaha ekonomi produktif

\section{ABSTRACT}

Dasawisma has the potential to improve family welfare through the productive efforts of dasawisma members. Some members of dasawisma 2 Gobayan RT 01 RW XI Makamhaji Village have skills in making food preparations but have not yet developed. The problems faced were a lack of understanding of entrepreneurship and the limitations of production equipment. This community service is done to overcome this problem. Activities undertaken include entrepreneurship training, introduction of production equipment (stick-making equipment, scales, and sealers), and mentoring. The results of this community service activity were members of dasawisma have knowledge about entrepreneurship, they were motivated to become entrepreneurs, and have production tools that can be used to make stick businesses. The results of monitoring and evaluation showed that members of dasawisma had made various flavor sticks and were then sold to stalls, sold online, and also received orders. These community service activities have led to productive economic bussines that are beneficial to increase the household income of the dasa wisma members.

Keywords: dasawisma, entrepreneurship, productive economic bussines

\section{PENDAHULUAN}

Kelompok Dasawisma adalah kelompok yang terdiri dari 10-20 kepala keluarga (KK) dalam satu RT. Setelah terbentuk kelompok, maka diangkatlah satu orang yang memiliki tanggung jawab sebagai ketua. Tujuan pembentukan kelompok dasawisma adalah untuk membantu kelancaran tugas-tugas pokok dan program Pemberdayaan dan Kesejahteraan
Keluarga (PKK) kelurahan. Dasawisma sebagai salah satu wadah kegiatan masyarakat memiliki peran yang sangat penting dalam pelaksanaan program-program kegiatan gerakan PKK di tingkat desa yang nantinya akan berpengaruh pula pada kegiatan gerakan PKK di tingkat Kecamatan dan Kabupaten.

Dasawisma merupakan bagian dari PKK yang mempunyai peranan sangat penting di masyarakat. PKK dan Dasawisma memiliki 
peranan yang penting dalam meningkatkan kualitas hidup masyarakat, seperti peningkatan kualitas kesehatan dan ekonomi. Dasawisma memiliki peranan yang sangat penting dan menjadi garda terdepan sekaligus ujung tombak dalam suksesnya 10 program PKK. Dasawisma berkontribusi luar bisa, bersinergi serta berkomitmen dalam menghadirkan berbagai program dan kegiatan yang sesuai kebutuhan masyarakat terutama peningkatan kualitas kesehatan dan ekonomi keluarga.

Salah satu peran yang dapat dilakukan oleh dasawisma dalam meningkatkan kesejahteraan keluarga khususnya dan masyarakat pada umumnya adalah mengembangkan kewirausaahan anggota dasawisma. Kewirausahaan adalah sebagai tujuan untuk menerapkan ide inovatif dan memanfaatkan peluang untuk mendapatkan sesuatu yang bernilai. Kewirausahaan memiliki proses yang dinamis untuk menciptakan sesuatu yang disertai tenggang waktu, modal, sumber daya dan juga resiko (Saiman, 2014). Kewirausahaan adalah suatu proses dalam melakukan atau menciptakan sesuatu yang baru dengan cara kreatif dan penuh inovasi yang memberikan manfaat bagi orang lain dan bernilai tambah.

Tujuan seseorang berwirausaha:

1. Membuka lapangan pekerjaan baru bagi orang lain dan membantu mereka untuk menjadi pengusaha mandiri.

2. Menciptakan jaringan bisnis yang baru yang dapat menyerap banyak tenaga kerja di sekitarnya.

3. Meningkatkan kesejahteraan hidupnya dan juga masyarakat di sekitar usaha yang dijalankan dengan membuka lapangan kerja.

4. Menularkan dan mengembangkan semangat berwirausaha kepada orang lain.

5. Membantu para pengusaha muda untuk berkreasi dan berinovasi.

Membangun bisnis yang besar berawal dari bisnis yang kecil. Bisnis tidak harus dengan modal materi yang besar namun juga disertai dengan modal moril yang tinggi. Dasawisma 2 Dusun Gobayan RT 01 RW XI Desa Makamhaji merupakan dasawisma yang baru terbentuk sehingga belum optimal melaksanakan fungsinya sebagai mitra pemerintah desa dalam mewujudkan kesejahteraan keluarga. Dasawisma 2 memiliki potensi untuk meningkatkan kesejahteraan keluarga melalui usaha produktif dari ibu-ibu anggota dasawisma. Usaha kecil adalah usaha ekonomi produktif yang berdiri sendiri, yang dilakukan oleh orang perorangan atau badan usaha yang bukan merupakan anak perusahaan atau bukan cabang perusahaan yang dimiliki, dikuasai, atau menjadi bagian baik langsung maupun tidak langsung dari usaha menengah atau usaha besar yang memenuhi kriteria usaha kecil sebagaimana dimaksud dalam UU No.20 Tahun 2008 tentang usaha kecil (Supriyadi, 2017).

Sebagian anggota Dasawisma 2 Dusun Gobayan RT 01 RW XI memiliki ketrampilan dalam pembuatan olahan pangan hanya saja belum dikembangkan. Padahal usaha pengolahan pangan (agroindustri) memiliki prospek untuk dikembangkan karena setiap manusia membutuhkan pangan. Kendala utama yang dihadapi adalah kurangnya pemahaman tentang kewirausahaan dan peluang berwirausaha serta keterbatasan sarana prasarana produksi. Soekartawi (2011) mengatakan bahwa pengembangan agroindustri pangan berkaitan erat dengan pembangunan pedesaan sehingga perlu peningkatan pengetahuan dan keterampilan pelaku agroindustri pangan. Oleh karena itu diperlukan pendidikan tambahan seperti pelatihanpelatihan.

Kusnandar (2013) menyatakan bahwa pengembangan ekonomi kreatif dapat dilakukan dengan berbasis pada lokasi dengan mengkreasikan menjadi sebuah nilai ekonomi dan berbasis sumberdaya manusia dengan mendorong tumbuhnya insan-insan kreatif. Penelitian Tini (2019) menunjukkan bahwa kegiatan pengembangan UEP (Usaha Ekonomi Produktif) tersebut memberikan dampak positif terhadap perempuan-perempuan yang ada di pedesaan, mereka dapat menghasilkan uang dan membantu para suami tanpa harus bekerja jauh di luar rumah. Berdasarkan latar belakang dan permasalahan tersebut, secara umum pengabdian ini bertujuan untuk mengembangkan usaha ekonomi produktif ibu-ibu anggota Dasawisma 2 RT 01 RW 11 Desa Makamhaji. Pada akhirnya diharapkan dari kegiatan ini muncul usaha produktif dari mitra dan mampu membantu meningkatkan pendapatan.

\section{METODE}

Kegiatan pengabdian dilakukan pada bulan April-Oktober 2019 yang dibagi dalam beberapa langkah/tahapan yaitu sosialisasi kegiatan, pelatihan kewirausahaan dan introduksi alat produksi, dan pendampingan 
selama kegiatan serta monitoring evaluasi terakhir kegiatan.

a. Sosialisasi Kegiatan

Tim pengabdian menyosialisasikan rencana kegiatan kepada ketua Dasawisma 2 Dusun Gobayan RT 01 RW XI, kemudian merencanakan pelaksanakan kegiatan yang akan dilakukan meliputi tanggal, tempat, dan sarana yang diperlukan dalam pelaksanaan kegiatan.

b. Penyuluhan dan Pelatihan Kewirausahaan Tim pelaksana berkoordinasi dengan mitra terkait dengan pelaksanaan pelatihan kewirausahaan. Penyuluhan kewirausahaan dilakukan oleh ketua tim pengabdian. Kemudian dilanjutkan dengan praktek kewirausahaan

c. Introduksi Alat Produksi

Tim pelaksana berdiskusi dengan mitra terkait dengan alat produksi yang diperlukan. Kemudian tim pengabdian memberi bantuan alat sesuai dengan kebutuhan dasawisma.

d. Pendampingan

Tim menyampaikan kepada mitra terkait dengan adanya pendampingan implementasi hasil pelatihan. Tim dan mitra merencanakan waktu dan kegiatan pendampingan.

\section{HASIL DAN PEMBAHASAN}

Kegiatan-kegiatan yang telah dilakukan pada pengabdian kepada masyarakat ini adalah:

\section{Penyuluhan dan Pelatihan Kewira- usahaan}

Pelatihan kewirausahaan dilakukan dalam rangka membekali anggota dasawisma dengan pengetahuan tentang kewirausahaan dan menumbuhkan jiwa wirausaha. Kegiatan penyuluhan kewirausahaan dilakukan dengan pemberian materi tentang kewirausahaan kepada ibu-ibu anggota Dasawisma 2 RT 01 RW 11
Desa Makamhaji Kecamatan Kartosuro Kabupaten Sukoharjo. Penyuluhan bertempat di rumah salah satu anggota dasawisma yaitu Ibu Emi. Kegiatan diawali dengan sambutan oleh ketua dasawisma yaitu Ibu Sri Rahadjoe. Ibu ketua dasawisma mengucapkan terima kasih kepada tim pengabdian atas kegiatan yang dilakukan dan berharap kegiatan pengabdian dapat bermanfaat untuk mengembangkan dasawisma dalam menjalankan tugas dan fungsinya khususnya terkait dengan pengembangan usaha ekonomi produktif untuk meningkatkan pendapatan rumah tangga. Selanjutnya diberikan penyuluhan mengenai kewirausahaan oleh ketua tim pengabdian yaitu Ibu Setyowati, S.P., M.P. Materi yang disampaikan meliputi pengertian kewirausahaan, kepentingan jiwa wirausaha, faktor-faktor yang harus dimiliki oleh wirausahawan dan diakhiri dengan memotivasi ibu-ibu anggota dasawisma untuk berani berwirausaha.

Ibu-ibu anggota dasawisma antusias mendengarkan materi yang disampaikan dan aktif dalam sesi diskusi dan tanya jawab. Kegiatan penyuluhan kewirausahaan disajikan pada Gambar 1.

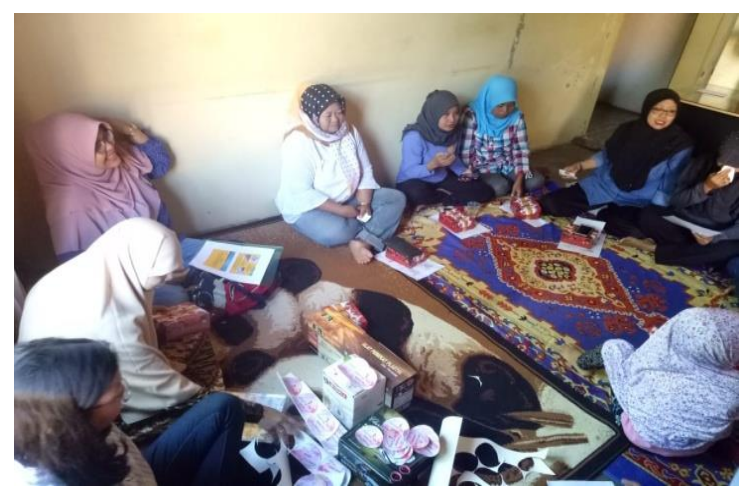

Gambar 1. Penyampaian Materi Kewirausahaan

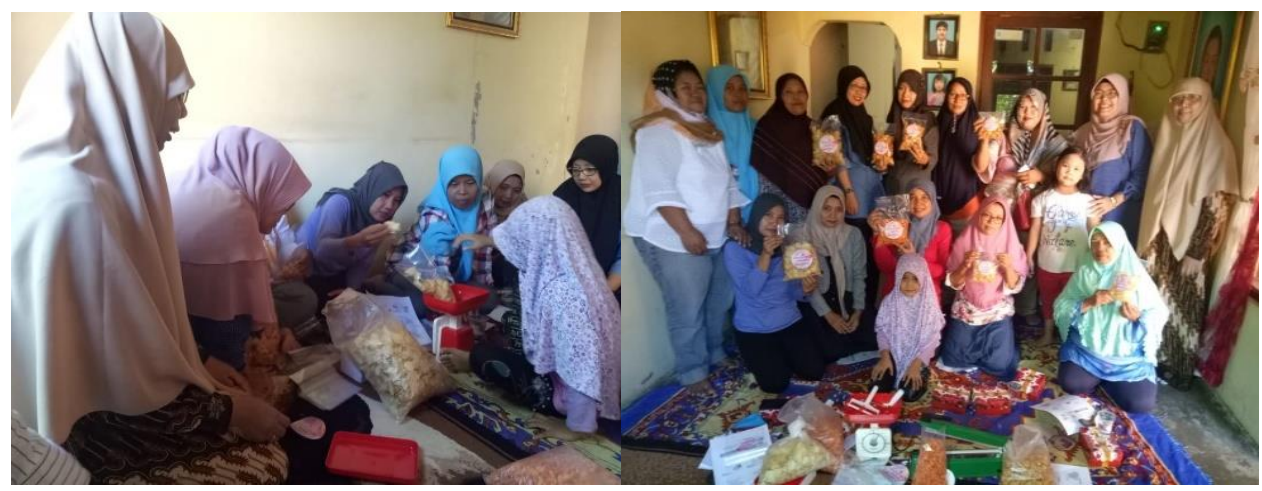

Gambar 2. Praktek Kewirausahaan 
Acara dilanjutkan dengan pelatihan kewirausahaan dengan melakukan praktek bisnis snack dengan mengemas aneka snack dalam kemasan besar dan kecil kemudian diberi label. Snack yang sudah dikemas kemudian dijual kepada anggota dasawisma. Kegiatan praktek kewirausahaan dapat dilihat pada Gambar 2.

Penyuluhan dan pelatihan kewirausahaan yang dilakukan pada kegiatan pengabdian ini memberikan pengetahuan tentang kewirausahaan dan memotivasi ibu-ibu untuk berani memulai usaha. Selanjutnya diharapkan pelatihan ini mendorong ibu-ibu anggota dasawisma untuk mengimplemantasikan dalam mengembangkan usaha ekonomi produktif.

\section{Introduksi Peralatan Pembuatan dan Pengemasan Stik}

Untuk menunjang kemampuan dasawisma dalam melakukan usaha ekonomi produktif, kegiatan pengabdian ini memberikan insentif berupa alat multiguna untuk pembuatan stik, molen, kulit pastel, pangsit, ataupun mie. Pemilihan introduksi alat pembuat stik dikarenakan stik merupakan makanan ringan (camilan) yang sudah dikenal oleh masyarakat, digemari, dan proses produksi mudah serta modal yang diperlukan tidak terlalu besar sehingga cocok untuk pengembangan usaha ekonomi produktif pada ibu-ibu dasawisma. Peluang bisnis stik bawang ini menguntungkan karena modal yang dibutuhkan tidak terlalu besar sehingga siapa pun bisa mencobanya. Proses memasak stik bawang ini hanya dengan cara menggorengnya saja sehingga waktu produksi hanya membutuhkan waktu sebentar.

Selain itu juga diberikan timbangan dan sealer untuk membantu pengemasan produk yang dihasilkan. Alat ini diberikan karena sebagian ibu-ibu anggota dasawisma memiliki kemampuan membuat berbagai olahan pangan tetapi terkendala peralatan yang tidak tersedia. Dengan introduksi peralatan ini diharapkan anggota dasawisma dapat menerapkan pelatihan kewirausahaan dengan melakukan usaha pengolahan pangan untuk dijadikan bisnis yang dikelola dasawisma. Bantuan sealer diharapkan dapat membantu dalam mengemas produk yang dihasilkan dengan lebih baik. Kemasan adalah salah satu hal yang dapat mempengaruhi penjualan produk di pasaran. Kemasan yang buruk atau kurang menarik dapat menyebabkan penurunan kualitas produk dan begitu juga sebaliknya (Nadira, 2017).

Peralatan diserahkan oleh tim pengabdian dan diterima oleh ketua dasawisma. Kegiatan introduksi peralatan produksi disajikan pada Gambar 3.

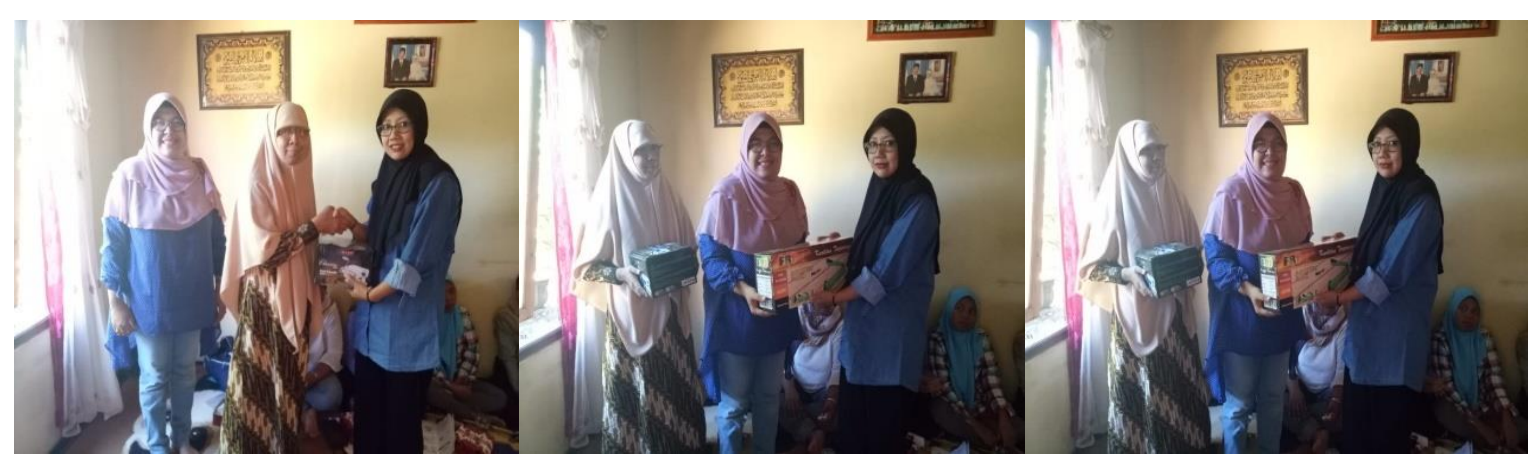

Gambar 3. Penyerahan Alat Pembuat Stik, Timbangan, dan Sealer

\section{Monitoring dan Evaluasi}

Kegiatan monitoring dan evaluasi dilakukan untuk memonitoring implementasi pelatihan kewirausahaan yang telah dilakukan. Monitoring dan evaluasi dilakukan dengan mendatangi langsung dasawisma. Berdasarkan hasil monitoring dan evaluasi diketahui bahwa ibu-ibu yang menjadi anggota dasawisma mengimplementasikan pelatihan kewirausahaan dan memanfaatkan bantuan alat dengan memproduksi stik aneka rasa. Kegiatan produksi stik aneka rasa oleh ibu-ibu dasawisma 2 RT 01 RW 11 Makamhaji disajikan pada Gambar 4.

Hasil produksi kemudian dikemas dan dijual dalam beberapa ukuran yaitu kecil, sedang dan besar. Harga kemasan kecil Rp $1.000,00 /$ bungkus dan Rp 2.000,00/bungkus, sedang $\mathrm{Rp} 5.000,00 /$ bungkus dan yang besar ukuran 1 (satu) kilogram dijual dengan harga Rp $30.000,00 / \mathrm{kg}$. Pemasaran produk dilakukan dengan menitipkan di warung, berdasarkan pesanan, dan juga dijual online. Hasil produksi dan pemasaran online disajikan pada Gambar 5. 


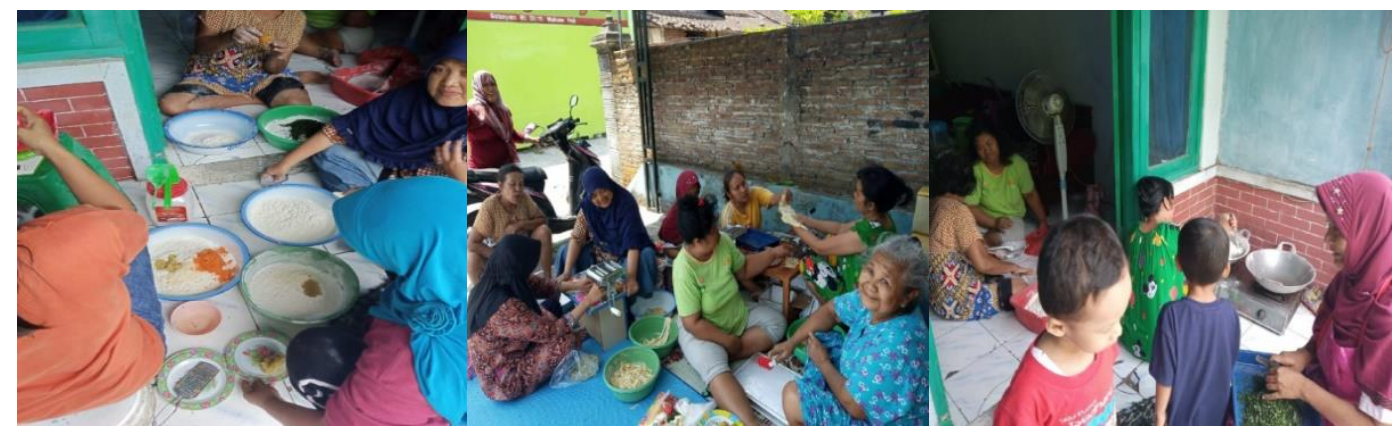

Gambar 4. Produksi Stik Aneka Rasa oleh Ibu-ibu Dasawisma

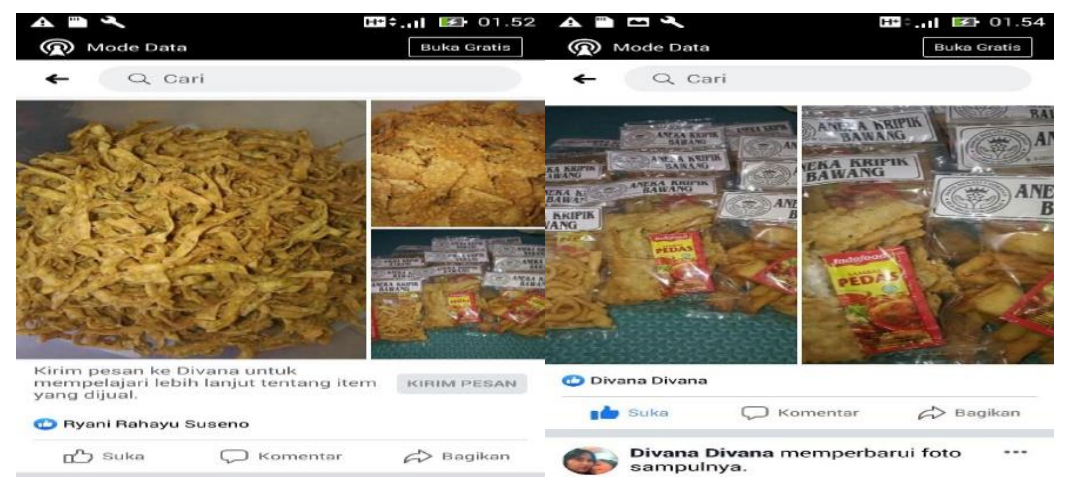

Gambar 5. Stik Hasil Produksi Ibu-Ibu Dasawisma

\section{Pendampingan}

Pengembangan usaha produktif secara berkelompok membutuhkan manajemen yang baik karena menyatukan berbagai kepentingan. Berdasarkan hasil monitoring diketahui salah satu masalah dalam pengembangan usaha adalah teamwork dan manajemen usaha. Ibu-ibu anggota dasawisma memiliki kesibukan masingmasing sehingga tidak mudah menyatukan dalam satu kegiatan produksi dan pemasaran secara berkelanjutan. Oleh karena itu tim pengabdian mendampingi dalam upaya menggerakkan tim. Salah satu solusi yang diberikan oleh tim pengabdian adalah menentukan koordinator produksi dan pemasaran. Koordinator bertanggung jawab untuk menjalankan usaha dan menggerakkan ibu-ibu yang lain dalam aktivitas produksi secara bergilir.

\section{KESIMPULAN}

Kegiatan pengabdian masyarakat telah dilaksanakan dan berjalan dengan lancar karena adanya kerjasama antara tim pengabdian dan mitra Dasawisma 2 RT 01 RW 11 Desa Makamhaji. Kegiatan yang sudah dilaksanakan meliputi: sosialisasi kegiatan, pelatihan kewirausahaan, monitoring dan evaluasi, dan pendampingan. Hasil kegiatan pelatihan kewirausahaan menunjukkan bahwa setelah mengikuti pelatihan, ibu-ibu anggota dasawisma memahami kepentingan kewirausahaan, termotivasi dalam berusaha, dan mengimplementasikan pelatihan yang diperoleh dengan membuat produk stik aneka rasa dan memasarkan secara offline dan online. Pada akhirnya kegiatan pengabdian yang dilakukan memunculkan usaha ekonomi produktif di Dasawisma 2 RT 01 RW 11 Desa Makamhaji yang bermanfaat untuk meningkatkan kas dasawisma dan pendapatan anggota kelompok.

\section{UCAPAN TERIMA KASIH}

Terima kasih kepada Ibu-ibu Dasawisma 2 Dusun Gobayan RT 01 RW XI Desa Makamhaji Kartosuro Sukoharjo yang telah mendukung terlaksananya kegiatan ini sehingga berjalan dengan baik.

\section{DAFTAR PUSTAKA}

Kusnandar. (2013). Perspektif Pengembangan Ekonomi Kreatif Berbasis Komoditas Pertanian di Pedesaan. In Seminar Nasional "Pengembangan Ekonomi Kreatif Berbasis Komoditas Pertanian di 
Indonesia." Surakarta: Fakultas Pertanian, Universitas Negeri Sebelas Maret.

Nadira, N. (2017). Perbaikan Desain Kemasan Pia Apel Dengan Menggunakan Metode Quality Function Deployment (QFD) (Studi Kasus Di UMKM Permata Agro Mandiri, Kota Batu). Universitas Brawijaya. Retrieved from http://reposi tory.ub.ac.id/4435/

Saiman, L. (2014). Kewirausahaan: teori, praktik dan kasus-kasus (Ed. 2). Jakarta: Salemba Empat.

Soekartawi. (2011). Pengembangan Agroindustri Pangan untuk Meningkatkan Kesejahteraan Petani dalam Format Baru Strategi dan Kebijakan Pembangunan
Pertanian Indonesia 2010-2014. Bogor: PT Penerbit IPB Press.

Supriyadi, D. (2017). Upaya Menumbuhkan Kegiatan Usaha Ekonomi Produktif Oleh Perguruan Tinggi. Coopetition Jurnal Ilmiah Manajemen, 8(1), 17-25. Retrieved from http://ikopin.ac.id/jurnal/index.php/c oopetition/article/view/2

Tini, D. L. R. (2019). Pengembangan Program Usaha Ekonomis Produktif dalam Pemberdayaan Perempuan di Kabupaten Sumenep. Jurnal Inovasi Ilmu Sosial Dan Politik, 1(2), 156. https://doi.org/10.33474/ jisop.v1i2.4801 